
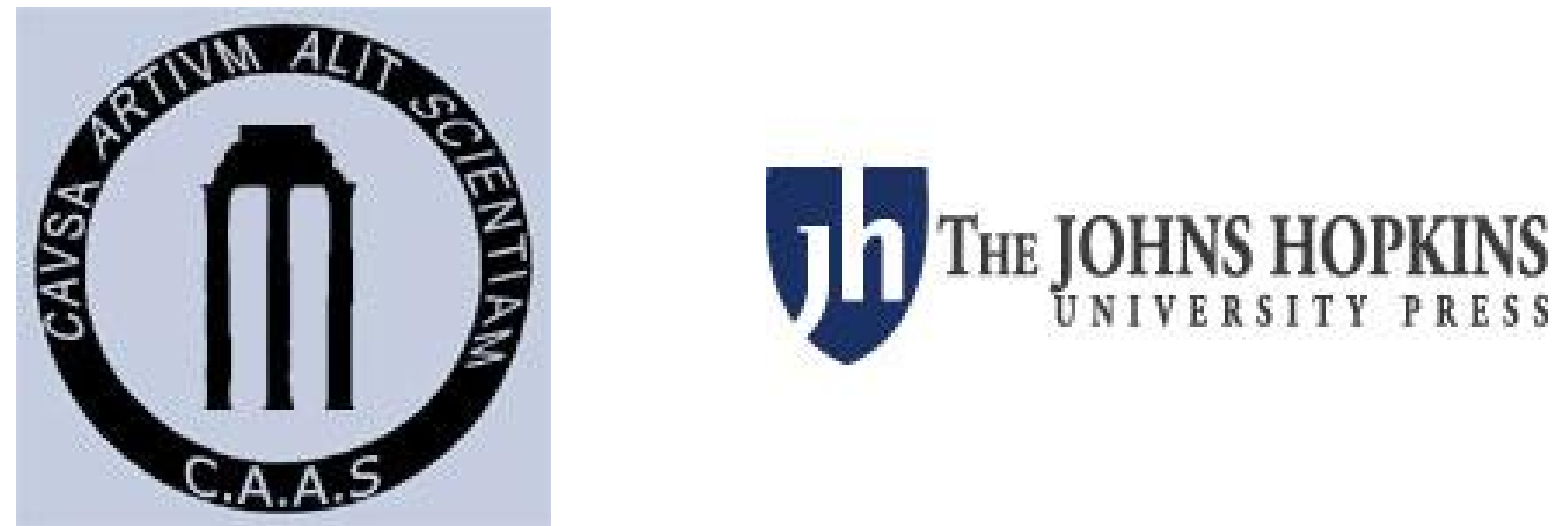

\title{
Varium Et Mutabile Semper Femina
}

Author(s): William R. Nethercut

Source: The Classical World, Vol. 72, No. 2 (Oct., 1978), pp. 101-103

Published by: The Johns Hopkins University Press on behalf of the Classical Association of the Atlantic States

Stable URL: http://www.jstor.org/stable/4348997

Accessed: 08-08-2016 18:22 UTC

Your use of the JSTOR archive indicates your acceptance of the Terms \& Conditions of Use, available at

http://about.jstor.org/terms

JSTOR is a not-for-profit service that helps scholars, researchers, and students discover, use, and build upon a wide range of content in a trusted digital archive. We use information technology and tools to increase productivity and facilitate new forms of scholarship. For more information about JSTOR, please contact support@jstor.org.

Classical Association of the Atlantic States, The Johns Hopkins University Press are collaborating with JSTOR to digitize, preserve and extend access to The Classical World 
allusion to the grounds of Sparsus' mansion in Rome:

... . rus in urbe est.

You have a veritable countryseat in the city.

It is in lines 15-17, 19-20 and 120 of his Sixth Satire, then, that we hear Boileau echoing Martial. Boileau, we have observed, follows the epigrammatist in protesting against the noise made by craftsmen, and in referring rather wist fully to the gardens of a rich man's urban estate.

\section{"VARIUM ET MUTABILE SEMPER FEMINA"}

In CW 71 (1977), 130, Richard M. Haywood argues that we ought not to rest content with the traditional interpretation of Mercury's warning. We have here, not (as T. E. Page, ad loc. supposes) the French catch:

"Souvent femme varie, bien fol est qui s'y fie,"

but instead, words with greater punch: "Woman is a creature of many moods and can change at any moment" (Haywood). What we need here is not some "silly. . .remark about the nature of women in general," but a sharp caveat calculated to motivate Aeneas' sudden departure-something urgent impressing the Trojan that Dido "may burst out in fury before dawn." This seems all the more true, since varium in 569 reinforces "variosque irarum concitat aestus" in 564: the explosive picture of the queen's present raving infects the general proposition, and it is as if in hearing varium, we are swept over by the tides of this specific woman's wildness. Dido is fluctuating right now. The statement of Mercury is aimed more at the moment than it is enunciated sub specie aeternitatis. Yet semper is a problem: we think of it as sketching an undifferentiated continuum ("always, forever"), but the sense we seek ("at any moment") is absent from Latin (Haywood).

Not from Greek, where aei, originally an Indo-European Locative whose native focus hence defined a given position at some time, meant not only "ever" but also something close to "at a given juncture, on any occasion"-something not too far from what we prefer Vergil to have written. Accordingly, in Homer, we find aei frequently coupled with expressions of continuity: e.g. emmenès aei ("constantly, on every occasion" Od. 21.69); synechès aei ("continuously without interruption, on every occasion"' $O d .9 .74)$.

Two possibilities exist for translation of the Greek adverb: (1) "now, at the present; for the time being"; (2) "on each, every occasion." At Apology $37 \mathrm{c}$, Socrates asks why he should drag out his days in prison, being a slave (douleúonta) to the established power (lế aei kathistaménei 
archei). Burnet translates "to the magistrates who hold office for the time being." Another rebel, Prometheus, hisses: sébou, proseúchou, thôpte tòn kratoûnt' aei ("Show reverence, pray to, fawn all over this ruler for the moment" PV 937); Zeus has only this short time now (tónde tòn brachỳn chrónon, 939) to sport his authority. Herodotus 2.98 (toû aei basileúontos) is referring to a particular ruler, one who was "in charge at the time"' (cf. Liddell \& Scott, vol. I, 26).

On the other hand, since Socrates asks what life would hold for him as a prisoner in chains, it may be better to take his words in Apology $37 \mathrm{c}$ as looking forward beyond the present situation alone, into the future. Aei would mean "at every moment." We read, then, "And why must I live in prison, a slave to the authority set in sway on every occasion?" Evidence for this second meaning, that aei = "on any, each, every occasion," is present in Herodotus 3.83, where Otanes states that he wishes neither to rule nor to be ruled, and withdraws himself from power so that neither he nor his posterity may serve another. The phrase hoi. . .aei ekginómenoi should mean "those who will be added to my line at any time hereafter." To say that ael means only "for all time to come, forever" is not precise: the continuum usually assigned to ael makes good sense if we are talking about one action, e.g. the gods ruling forever (hoi aei ontes); here, however, there is no continuum which reaches forever, but rather a plurality of separate specific births (hoi ap'emêे aei ekginómenoi) - taking place on separate specific occasions. Ael is an adverb closely tied to the plural; it is not possible to take it apart from the Greek word order and cause it to hang freely in a kind of general application to the entire sentence ("My descendents forever will be free').

In Demosthenes 21.223 , we find the orator exhorting the jury to consider why it is able to exercise the authority it possesses in a healthy state: "For indeed, if you would wish to look at and inquire into the very reason whereby, on every occasion (pot') you have the men who are dicasts at the time (hoi aei dikázontes) strong and in command of all the affairs of the city. .." The enclitic pote, "ever, at any time", directs our understanding of aei to be centered on that "any time" the speaker envisions us taking for an example.

Thucydides, too, illustrates this second sense of aei. In 1.97, toùs aei prostychánontas is translated "who in several incidents were coming into contact with them" (E. C. Marchant). In 4.68, ho aei entòs gignómenos ("every one as he came inside," Liddell \& Scott, vol. I, 26) is construed to bring out the entry of each individual figure: an identification is made of each instance on which someone is coming in. A final example, from Demosthenes 21.131, toǹ aei prostychónta, concludes the argument that aei could be taken to mean "at any time." The aorist participle must refer to one specific action that has been completed, yet we find it modified by aei: no chance here for anything being "always" or "forever;" what we are talking about is a one-time thing, done. The sense is "Whomever, at any time. . ."

Vergil tinges the Aeneid with Greek color. He wants to succeed Homer. He was fully capable of causing semper to carry the tone $\mathrm{Mr}$. 
Haywood deems appropriate here. All the more so would it be appropriate for the Messenger of the Gods, Mercury (modeled at this moment on Hermes who takes to Calypso in Odyssey 5 Zeus' word that Ulysses is now to leave her and move onward), to speak like a Greek. A good parallel for just this kind of Vergilian employment of Greek sense in a commonplace word is offered by the famous verse: timeo Danaos et dona ferentes (A. 2.49). Latin dictionaries do not say that $e$ can be the adverb "even," but it is, here. Vergil was thinking of the Greek word kal, which means both "and" and "even." It is wry, or perhaps just, that Laocoon, facing a Greek gift, utters, in this Greek sense, the word which precedes dona.

University of Texas at Austin

WILLIAM R. NETHERCUT

\section{AGAIN: "VARIUM ET MUTABILE SEMPER FEMINA"}

Mr. Haywood's observations ( $C W 71.2)$ on this line would seem to assert the obvious. The omission of the copula regularly applies to the present tense, which is why the translation "woman was ever varied and changeable" is not only "flat and weak," as Mr. Haywood rightly remarks, but incorrect; and all translators worth their salt have either used the present tense or stated "has ever been," the implication being "and still is."

Furthermore, it seems obvious to me that semper in the sense of "at any time" is implicit in the meaning "always, at all times" so that we need not assume that Vergil here "forces" the word.

Mr. Haywood's suggested translation "Woman is a creature of many moods and can change at any moment" has been anticipated by numerous translators. Old Conington writes: "A thing of moods and changes is woman ever," while Rolfe Humphries has: "A shifty, fickle object is woman always." F. Jackson Knight has: "Women were ever things of many changing moods." M. Oakley also echoes Mr. Haywood's translation: "Fickle and inconsistent - so woman has always been, a changeable creature."

The underlying threat is brought out by Patric Dickinson: "Women are always changeable and violent." So far from being "a rather sententious and silly remark on the nature of women in general," the threat of possible violence by "a woman scorned" is so clear that in the next line Aeneas is subitis exterritus umbris - something a general platitude ("It is a lady's privilege to change her mind") would not have produced. However, the observation is not "rather sententious": it is a sententia. 